\title{
LLGL1 wt Allele
}

National Cancer Institute

\section{Source}

National Cancer Institute. LLGL1 wt Allele. NCI Thesaurus. Code C91767.

Human LLGL1 wild-type allele is located in the vicinity of $17 \mathrm{p} 11.2$ and is approximately 19 $\mathrm{kb}$ in length. This allele, which encodes lethal(2) giant larvae protein homolog 1 protein, plays a role in the regulation of mitotic spindle orientation, cell proliferation, neuroepithelial cell differentiation, tumor suppression and cytoskeletal maintenance. Aberrant expression of the gene is associated with the progression of both colorectal cancers and melanoma. 